\title{
Babaların Madde Kullanımı Tedavisine Katılımları Üzerine Nitel Bir Araștırma
}

\section{A Qualitative Study on Fathers' Participation in Substance Use Treatment}

\author{
ه Illker AKTÜRK ${ }^{1}$, Đ Ömer Miraç YAMAN ${ }^{1}$ \\ ${ }^{1}$ İstanbul Üniversitesi-Cerrahpaşa, Cerrahpaşa Lisansüstü Eğitim Bilimleri Enstitüsü, İstanbul, Türkiye
}

\section{$\ddot{\mathrm{O} z}$}

Amaç: Madde kullanım tedavisinde babaların ișlevleri hakkında yeterli bilgi bulunmamaktadır. Babanın bağımlılık tedavisindeki yerinin belirlenmeye çalışılması bu çalışmanın birincil amacını oluşturmaktadır.

Yöntem: Araștırmada 20 madde kullanıcısı ve 20 madde kullanan oğlu olan baba ile derinlemesine görüșmeler gerçekleștirilmiștir. Yapılan görüşmelerden elde edilen veriler, nitel veri analiz yöntemlerinden birisi olan betimsel analiz yöntemi kullanılarak analiz edilmiştir.

Bulgular: Bu bağlamda Babalarda Eksik Tedavi Katılımı, Tedaviye Katılımda Babalar için Motivasyon Kaynağı Olarak Başarı Hikayeleri ve İyileșme Arzusu, Tedavi Sürecinde Baba Katılımının İșlevi, Tedavide Doğru Bilgi ve İlișki Ağını Yakalamak, Tedavi Sürecine Katılımda Anne ve Baba Arasındaki Farklar olmak üzere 5 farklı tema saptanmıștır.

Sonuç: Çalıșmanın sonucunda babaların madde kullanım tedavisine yeterli katılımı sağlamadıkları, daha çok maddi destek să̆layan tarafta oldukları anlașılmıștır. Bununla beraber, iyileșmiş madde kullanıcıları ile tanıșmak veya tedavi için umut sahibi olmak babaların tedavi katılımlarını etkilemektedir. Çalışmada öne çıkan bulgulardan bir diğeri, babaların tedavi katılımının tedavi sürecini olumlu etkileme potansiyelinin yanında, sürece zarar verici nitelik taşıyabilmesidir. Tedavi sürecinde babaların hızlı şekilde hayal kırıklığı yașayabildiği ve tedavinin dıșında kalabildiği dikkate alındığında, babaların doğru bilgive ve doğru kaynağa ulaşmasının önemi oldukça büyüktür. Son olarak, tedavi sürecine katılımda anne ve baba arasında önemli farklar tespit edilmiştir. Baba maddi destek sağlarken, anne manevi destek sağlamakta ve babaya karșı çocuğunun yanında yer almaktadır.

Anahtar kelimeler: Bağımlılık, madde kullanımı, baba, babalık, madde kullanımı tedavisi

\section{Abstract}

Objective: There is not enough information about the functions of fathers in substance use treatment. The primary aim of this study is to try to determine the father's position in addiction treatment.

Method: In this context, in-depth interviews were conducted with 20 substance users and 20 fathers of substance users. The data obtained from the interviews were analyzed using the descriptive analysis method, which is one of the qualitative data analysis methods.

Results: Five different themes have been identified: Deficient Treatment Engagement in Fathers, Success Stories and Desire for Recovery as a Motivation Sources for Fathers in Engagement in Treatment, Function of Father's Engagement in the Treatment Process, Create the Right Information and Relationship Network in Treatment, Differences between Mother and Father to Engagement in the Treatment Process.

Conclusion: Fathers did not provide adequate participation in substance use treatment, and they were on the side that provided more financial support. However, meeting recovered substance users or having hope for treatment affects fathers' participation in treatment. Another prominent factor in the study is that fathers' participation in treatment can have a positive effect on the treatment process and may have significant effects on termination. Considering that fathers can quickly become disappointed and stay out of treatment during the treatment process, fathers need to reach the right information and the right source. Finally, significant differences were identified between mothers and fathers in participation in the treatment process. While the father provides financial support, the mother provides moral support and stands by her child against the father.

Keywords: Addiction, substance use, father, fatherhood, substance use treatment

Not: Bu çalıșma 1. Yazarın İstanbul Üniversitesi-Cerrahpaşa, Cerrahpașa Lisansüstü Eğitim Bilimleri Enstitüsündeki Yüksek Lisans tezinden üretilmiștir. 


\section{Giriş}

Bağımlılık çok bileșenli ve sosyal etkileri bulunan bir bozukluktur (1). Bu sosyal etkilerin odağında ise aile bireyleri veya bakım verenler yer almaktadır. Nitekim bağımlıık aileden kaynaklı değişkenlerden beslenebilmesi ve aileyi ciddi derecede etkilemesi sebebiyle sıklıkla bir aile hastalığı olarak tanımlanmaktadır (2). Bu sebeple, aile, madde kullanımından ve bağımlııktan etkilenirken aynı zamanda da bu durumu etkileyen bir yapı arz etmektedir. Ailenin süreçteki etkisinin daha iyi anlaşılması, madde kullanıcısının tedavisinde, ailenin tedavi katılımını artırma noktasında ișlevsel olabileceği düşünülmektedir zira yapılan araștırmalar ailenin tedavi sürecine katılımının pozitif tedavi çıktılarıyla karakterize olduğunu ortaya koymaktadır (3-6).

Ailenin tedaviye katılımının artması, hem danışanın tedavi katılımını artırarak tedavi çıktısında dolaylı etki yapmakta hem de direkt olarak istenilen tedavi çıktılarına ulaşma noktasında önemli işlevleri bulunmaktadır (2). Hornberger ve Smith'e göre madde kullanımı noktasında aileler genellikle sorunun bir parçası veya nedeni olarak görülmekteyken, ailelerin aynı zamanda çözümün de önemli bir parçası olabilecekleri gözden kaçırılabilmektedir (3). Bu sebeple ailelerin tedavi katılımlarının artırılması önem tașımaktadır. Orford'a göre yakınları bağımlılık tedavisi alan ailelerin eș zamanlı olarak bir tedavi sürecine dahil olmaları veya paralel olarak takip edilen bir tedavi programının parçası olmaları pozitif tedavi çıktıları açısından önem taşımaktadır (4). Copello ve arkadaşları tarafından yapılan çalıșmaya göre ise aile ile çalıșmak, madde kullanıcısının tedaviye bașlamasını ve tedaviyi sürdürmesi üzerinde etkili olabilmektedir (5). Bu noktada ailenin, madde kullanan yakını tedaviye katılmasa dahi, tedavi sürecine bașlaması, madde kullanan yakını için istenilen sonuçların elde edilmesini ve yakınının tedavi girişiminde bulunmasını sağlayabilmektedir (6). Bischof ve arkadașlarının yaptığı bir çalıșmada da madde kullanan yakını için tedavi programına dahil olan ailelerin, yakınlarının tedavi katııımlarını ve tedavi girişimlerini artırdığı ortaya çıkmışıı (7). Kahyaoğlu ve arkadaşlarının Türkiye'de yaptığı bir çalıșmaya göre madde kullanımı tedavisinde aileler ile 3 ve daha fazla üzerinde yapılan görüşmeler, daha az veya hiç yapılmayan görüșmelere kıyasla, yakınlarının tedaviye yaklașık 2,5 kat daha fazla katılımını sağlamaktadır (2). Bununla beraber, ailenin tedavi katılımı arttıkça, madde kullanan yakınının bu süreçteki madde kullanımı da azalma eğilimi göstermekte ve tedavi sürecinde olan madde kullanıcılarının tedaviden ayrılma oranlarını düșürmektedir. Elde edilen bu sonuçlar, ailelerin tedavi kapsamında, profesyonel destek sağlayıcılar ile yaptıkları görüșmelerin, tedavinin etkililiği adına önemli işlevi olabileceğini ortaya koymaktadır. Bu bağlamda sonuçlar, ailelerin tedavi katılımlarını artırmaya yönelik girișimleri destekler niteliktedir (2).
Ailelerin, tedaviye katılım sağlamaları ve sürecin parçası haline gelmeleri, istenilen tedavi çıktıları ile karakterize görünse de sürecin içerisindeki aktörlere ilişkin bazı belirsizlikler bulunmaktadır. Öyle ki, aile ile kastedilenin ailenin hangi üyesi olduğu veya ailenin tamamının kastedilip edilmediği önem taşımaktadır. Zira, madde kullanım tedavisinde tedaviye daha çok katılım sağlayan aile üyesinin anneler olduğu ve babaların tedaviye anneler kadar katılım sağlamadığı bilinmektedir (8). Yine, araștırmalarda aile veya ebeveyn şeklindeki kullanımların genel itibariyle anneleri içerdiği, başılı̆ında aile veya ebeveynler şeklinde atıfların bulunduğu çalışmalarda katılımcı grubun çoğunlukla annelerden oluştuğu bilinmektedir (9-13). Bu durum yalnızca bağımlılık alanında değil, literatürün büyük bölümünde benzer bir seyir izlemektedir. Dolayısıyla madde kullanım süreci ve tedavisinde babaların ișlev ve etkisine ilișkin belirsizlikler bulunmaktadır. Zira iletişim amacıyla babalara ulaşmak, annelere ulaşmaktan daha zor olabilmektedir. Bununla birlikte, yapılan araştırmalar madde kullanımı ve babalar arasında önemli ilișkiler kurmaktadır. Örneğin Caliendo ve arkadaşlarının yaptığı bir çalışmada babaların çocuklarına yönelik olan reddedici tavırlarının, çocuklarının madde kullanımı üzerinde etkili unsurlar arasında olabileceği belirtilmektedir (14). Begum ve Mahmood (2) tarafından yapılan başka bir çalışmada da benzer sonuçlara ulaşılmış, madde kullanan çocuğu olan babaların annelere kıyasla daha yüksek seviyede reddedici tutumlara sahip olduğu anlaşılmıştır (11). Bess ve ark. tarafından yapılan çalıșmada ise babalar ve çocukları arasındaki ilișkinin, çocukları madde kullanımından koruyabilecek nitelikler tașıdığı ortaya koyulmuștur (12). Eldred ve ark.'nın (10) yaptığı bir çalıșmada ise madde kullanıcılarının, madde kullanıcısı olmayanlara kıyasla babalarına ilişkin daha olumsuz tanımlamaları ve negatif tutumları olduğu anlaşılmaktadır. Araştırmalara bakıldığında babaların, madde kullanım sürecinde önemli bir rol oynadığını ancak annelerin süreç içerisindeki aktif katılımının, babaların yerine annelerin daha çok konuşulmasını sağlamış olabileceği düşünülmektedir (13).

Babaların, madde kullanım sürecindeki etkilerin boyutu ve tedaviye annelere göre daha az katılmaları düşünüldügüünde tedavi üzerindeki etkilerini betimlemenin önemli olduğu düșünülmektedir. Dolayısıyla bu çalıșmada babaların, madde kullanan çocuklarının bağımlıık tedavisi üzendeki etkilerinin ve yine babaların bu süreçte oynadıkları rolün ortaya çıkarılması amaçlanmıştır.

\section{Yöntem}

Çalıșmada madde kullanımı tedavisinde, babaların yerinin betimlenmesi amaçlanması sebebiyle nitel araştırma yöntemleri kullanılmışır. Zira nitel araştırma yöntemleriyle, ilgilenen olgunun daha detaylı analizinin yapılması mümkün hale gelmektedir. Üzerine çalışılan olgunun daha derinlemesine ele 
alınmasını amaçlamak adına nitel araştırma yöntemlerinden fenomenolojik desen kullanılmıştır. Böylelikle katılımcıların hikayeleri ve söylemleri üzerinden belli fenomenlerin incelenmesi amaçlanmıştır (14). Bu çalışmanın etik kurul onayı 03.12.2019 tarihinde 2019/141 karar no ile İstanbul ÜniversitesiCerrahpaşa, Cerrahpaşa Sosyal ve Beșerî Bilimler Araștırmaları Etik Kurulu'ndan alınmıștır. Katılımcılardan aydınlatılmış onam alınmıştır.

\section{Örneklem}

Bu çalıșmanın örneklemini 20 erkek madde kullanıcısı ve 20 madde kullanan çocuğu olan baba oluşturmaktadır. Katılımcılara ilișkin özellikler Tablo 1 ve Tablo 2'de yer almaktadır. Örneklemin olușturulmasında amaçlı örnekleme yöntemi benimsenmiş ve ölçüt örnekleme kullanılmıştır. Ölçüt örnekleme, araștırmaya katılımda bazı kriterlerin belirlenmesi ve bunlara göre örneklemin oluşturulması olarak tanımlanabilir (15). Örneklem sayısı ise kuramsal örnekleme tekniği ile belirlenmiștir. Kuramsal örnekleme yaklaşımında araștırma sonuçlarının doyum noktasına ulaşması veya elde edilen veriler birbirini tekrar etmeye bașlaması durumunda yeni katıımcıların örnekleme dahil edilmesi durdurulmaktadır (15). Bu çalıșmada da 20 madde kullanıcısı ve 20 madde kullanıcı çocuğu olan baba ile yapılan görüșmelerin ardından sonuçların doyum noktasına ulaștığı tespit edilmiş ve yeni görüșmeler yapılmamış, planlanan görüşmeler ise iptal edilmiştir.

Çalışma iki farklı grup ile yürütülmesi sebebiyle, her iki grup içinde örnekleme kriterleri birbirinden farklı olarak belirlenmiştir. Lakin bu kriterlerin birbiriyle uyum içinde olmasına ve çelişmemesine dikkat edilmiştir. Bu bağlamda madde kullanıcısı katılımcılar için; en az 1 kez ayaktan veya yatılı madde kullanımı tedavisi girișiminin olması, aktif psikoz tablosunun bulunmaması, araștırmacı ile daha önce psikoterapi ekseninde görüşme yapılmamış olması ve ailesinden başka bir üyenin (babanın) araştırma amacıyla görüşülenler arasında yer almaması olarak belirlenmiștir. Madde kullanan çocuğu olan babalar için; en az 1 kez ayaktan veya yatılı madde kullanımı tedavisi alan madde kullanıcısı çocuğu olması, araștırmacı ile psikoterapi ekseninde bir görüșme gerçekleștirmemiș olması ve ailesinden bașka birinin (madde kullanan çocuğu) araştırmaya katılmamış olması şeklinde kriterler belirlenmiștir. Katılıma grupların belirlenmesinde dikkat edilen diğer bir önemli kriter ise aynı aileden hem baba hem de madde kullanan kişiyle görüşülmemesidir. Böyle bir tercihte bulunulmasının en önemli amacı araştırmanın özellikle tedaviye devam eden katıımcıların tedavi sürecine herhangi bir etkide bulunmasının önüne geçmektir. Araștırmanın veri toplama sürecinde görüșülen 1 katılımcı, "araştırmacı ile psikoterapi ekseninde bir görüşme gerçekleștirmiş olmaması” kriterine uyum sağlamadığı anlaşılmış ve araştırmanın dışında bırakıımıştır.
Tüm katılımcılar yukarıdaki kriterler doğrultusunda gönüllülük esasına göre araştırmaya katılım sağlamıștır. Araştırmaya katılım konusuna gönüllü olanlar, bilgilendirilmiş onamları alındıktan sonra sürece dahil edilmişlerdir. Örnekleme ulaşmada ayaktan veya yatılı madde kullanımı tedavi ve danışmanlık desteği sunan sivil toplum kuruluşları ile bireysel çalışan meslek elemanlarından destek alınmıștır. Araştırmaya katııımın özellikle tedaviye devam edenler açısından olumsuz bir etki uyandırmayacağına kanaat getirilmesinin (sivil toplum kuruluşlarındaki uygulayıcılarının ve meslek elemanlarının görüșü doğrultusunda) ardından süreç bașlatılmıștır.

Araștırmaya katılım sağlayan kişilerin isimleri, söylem kolaylığını elde etmek adına değiştirilmiş ve takma isimler kullanılmıştır.

\section{Araștırmacının Konumu}

Nitel araştırmalar, genellenebilirlik kaygısı taşımayan ve nesnelliğin yerine anlamın ön plana çıkartıldığı çalıșmalar olarak ifade edilmektedir (15). Dolayısıyla araștırmayı yürüten kișinin, araștırma sürecindeki konumunun betimlenmesi önem arz etmektedir. Zira bireylerin doğasını ve kişilerarası ilişkilerini inceleyebilmek ve anlamlandırarak yorumlayabilmek adına araștırmacı ve araștırılan grup arasında bir aşinalı̆̆ın var olmasının önemli olduğu bilinmekte ve araștırmacının, araştırılan gruba yakınlığı verilerin gerçekçiliğini sağlayabilmesi adına önem arz etmektedir (15). Çalıșmayı yürüten araștırmacının alkol-madde kullanımı ve davranışsal bağımlılıklar alanında ruh sağ|ı̆̆ hizmeti veren bir sosyal hizmet uzmanı olması bu bağlamda gerekli yeterliliği sağlayabilecektir. Bununla beraber, araștırmacının araștırılan gruba yakınlığı bazı sorunları da beraberinde getirmektedir. Bunlardan en önemlisi, araștırmacının madde kullanııları ve babalarıyla yaptığı profesyonel görüșmelerde aradaki ilișkinin genel itibariyle negatif bir yapıya sahip olduğuna ilișkin gözlemdir. Bu yönüyle araştırmanın tam bir objektiflik ile çalışmaya bașlamasının önüne geçildiği düșünülebilir. Lakin yorumlayıcı paradigmaya ve bunun bir ürünü olan nitel yöntemlere göre araștırmacının, bir konuya ilișkin \%100 objektiflik sağlaması mümkün değildir. Burada kritik olan nokta, araştırmacının bu noktadaki ön yargılarının ve araștırma grubuna ilișkin geçmiş gözlemlerinin farkında olarak araştırma sürecinde dahil olmasıdır. Ancak bu şekilde araştırmacı geçmiş gözlemleri ve ön yargılarından arınarak araştırma sürecini geçerli ve güvenilir şekilde yürütebilecektir (15). Bu sebeple, araştırmacı gerek soru forumunun hazırlanması gerekse görüșmeler sonucunda elde edilen verilerin analizi ve yorumlanması noktasında bu noktalar göz önünde bulundurularak hareket etmeye gayret göstermiștir.

\section{İşlem}

Nitelaraştırmalarda pekçokveritoplamayöntemi bulunmaktadır. Bunlardan en çok kullanılanları arasında yer alan derinlemesine 


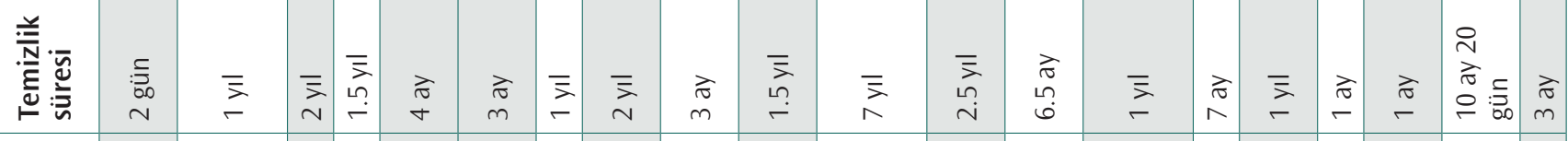

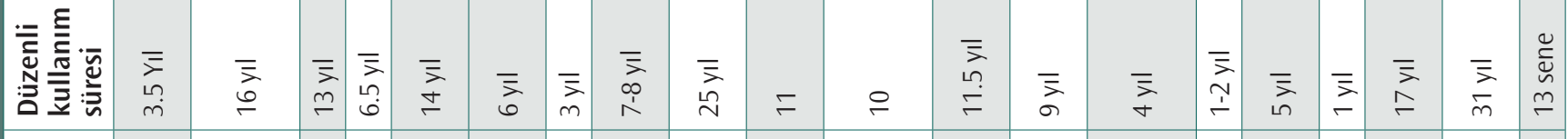

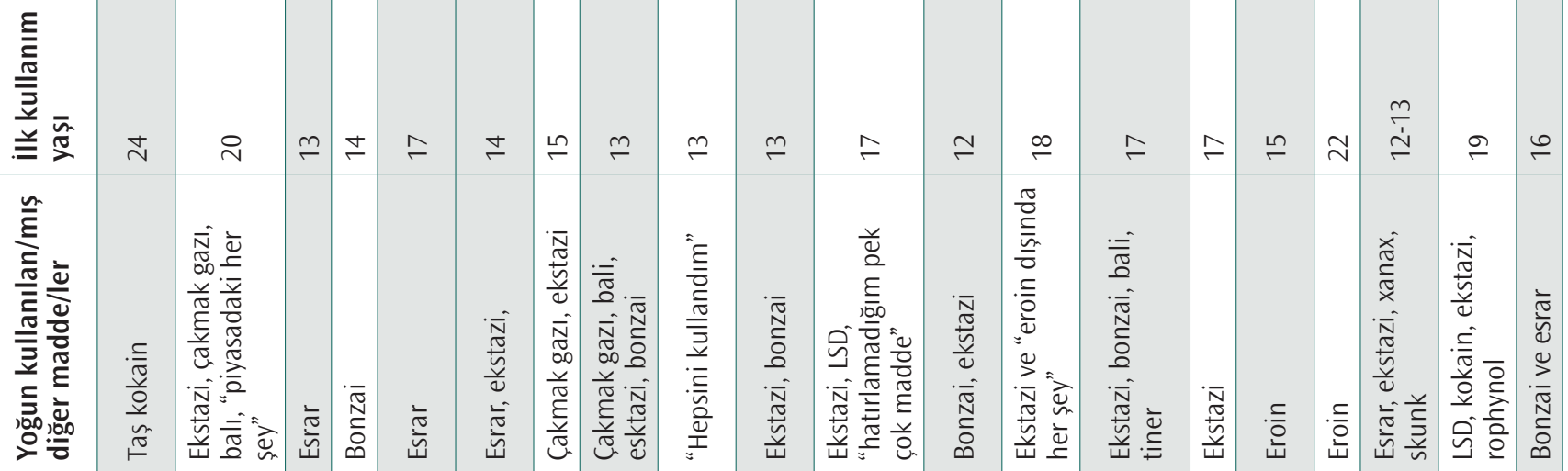

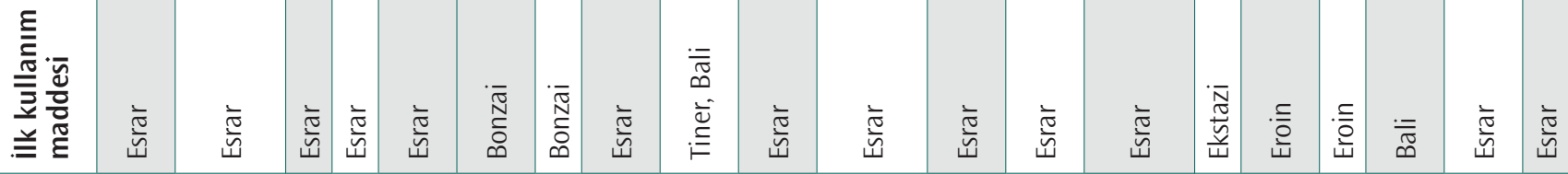

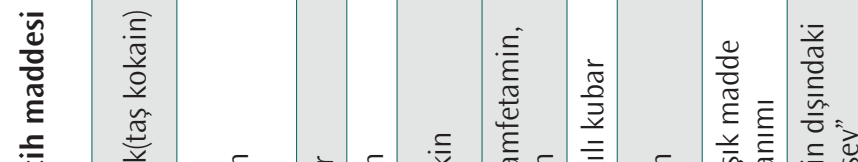

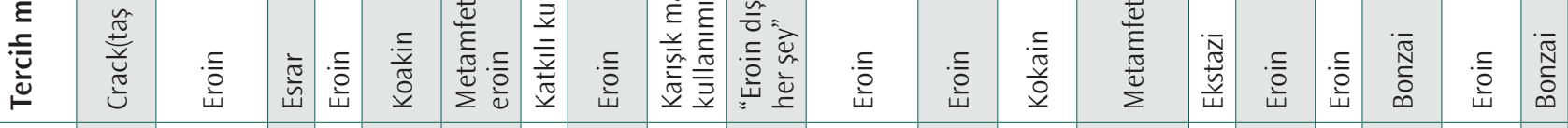

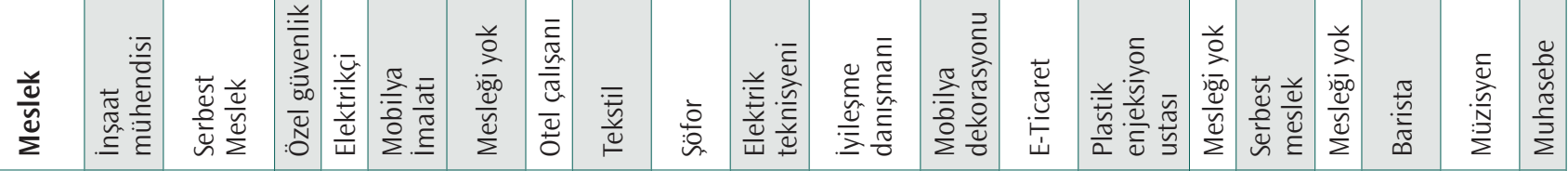

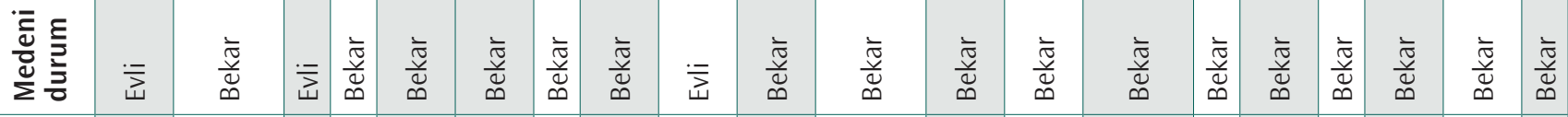

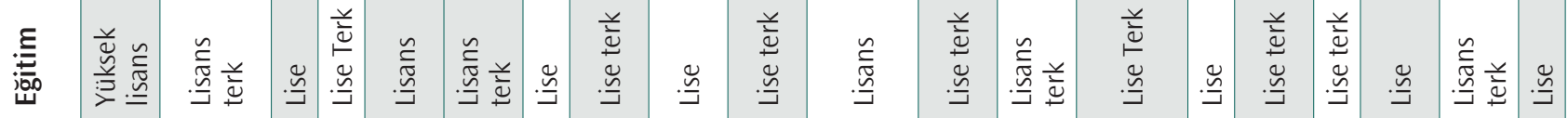

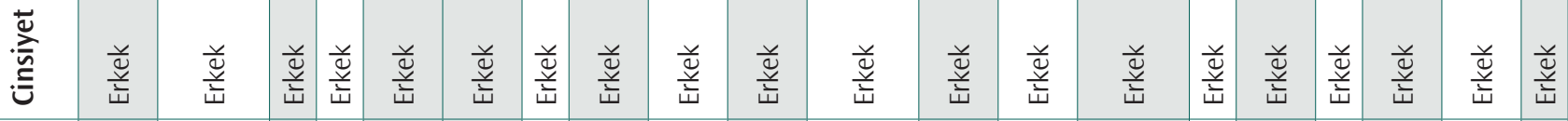

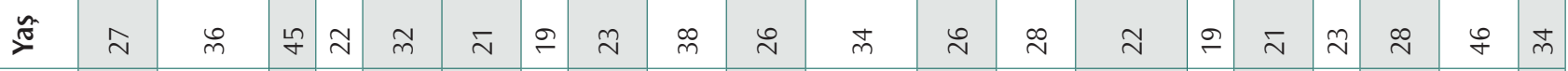

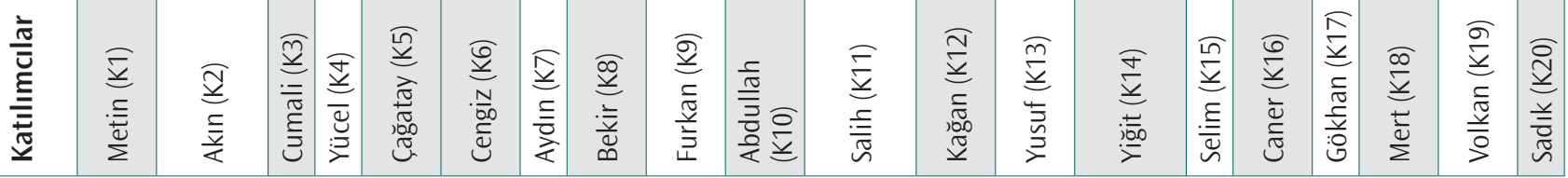


görüşme tekniği bu çalışmada veri toplama yöntemi olarak tercih edilmiștir (16). Madde kullanıcıları ve madde kullanıcısı çocuğu olan babalar ile yapılan bireysel görüșmeler, araștırmanın veri toplama yöntemini olușturmaktadır. Araștırmanın veri toplama sürecinde madde kullanıcıları ile yürütülen görüșmeler, babalar ile yürütülen görüșmelerden daha kısa sürede tamamlanmıștır. Madde kullanıcılarına ulaşmak ve gönüllü katılımlarını sağlamak, madde kullanıcısı yakını olan babalara ulaşmak ve onların araştırmaya katılımını sağlamaktan daha kolay ve daha kısa sürede gerçeklemiş̦tir. Bu noktada madde kullanıcısı çocuğu olan babalarda araștırmaya katılımda düșük gönüllülük olduğu gözlemlenmiștir. Araştırma sürecinde özellikle madde kullanıcısının madde kullanımına ilișkin çeșitli özellikleri, katılımcının onayıyla birlikte destek aldığı merkezden toplanmıştır. Temiz kalınan süre, kullanım maddeleri, kullanım yöntemi gibi bilgiler katılımcı tarafından dile getirilmemişse, bu yöntem kullanılarak bu verilere ulaşılmışıtır.

\section{Veri Toplama Araçları}

Bireysel görüşmelerde kullanılması amacıyla yarı yapılandırılmış görüşme formu geliștirilmiștir. Araştırmada iki farklı grup bulunması sebebiyle, bu iki grup için iki farklı görüșme formu hazırlanmıştır. Formların geliștirilme aşamasında babalar için 66, madde kullanıcıları için 35 soruluk bir havuz hazırlanmıștır. Ardından bu sorular üzerinde bir değerlendirme yapılmış ve soruların tekrar etmesi, benzer bilgilere ulașmaya yönelik sorular olması, araştırmacının konumu gereği ön kabuller içermesi gibi kriterler baz alınarak sorularda eleme yapılmıştır. Bu eleme süreci, gençlik çalışmaları yürüten ve madde kullanıcıları ile çalıșma deneyimi olan uygulayıcı ve akademisyenlerin desteği ile gerçekleștirilmiștir. Sonuç olarak madde kullanan çocuğu olan babalara ilișkin 10, madde kullanıcısı katılımcılara ilișkin 9 sorudan oluşan yarı yapılandırılmış görüșme formu oluşturulmuştur. Bu formlar 3 pilot görüşme ile test edilmiş ve formlar üzerinde gerekli görülen değișiklikler yapılmıștır. Son durumunda babalar için 13, madde kullanıcıları için 11 sorudan oluşan yeni formlar ortaya çıkmıștır. Bu formlar kullanılarak yapılan görüssmelerde katılımcıların önceden onayı alınarak görüșmeler ses kaydına alınmıștır.

\section{Veri Analizi}

Araștırmanın veri toplama süreci sonra erdikten sonra elde edilen veriler analiz edilmiștir. Bu analizi yapılırken, araștırmacının verileri kendi yorumuyla yeniden değerlendirerek sunması anlamına gelen betimsel analiz yöntemi benimsenmiștir (15). Verilerin analizi için öncelikle görüssmeler sırasında alınan ses kayıtları deșifre edilmiștir. Toplamda 32 saatlik ses kaydı deşifresinin ardından 372 sayfalık deşifre metni ortaya çıkarılmışıır. Çalışmada iki farklı grup olması sebebiyle, iki farklı deșifre metni ortaya çıkmış ve bu metinler kendi içlerinde değerlendirmeye tabii tutulmuştur. Yapılan değerlendirme ve analiz sürecinde metinlerde kodlama işlemi yapılmıștır. Bu ișlemin sonucunda 25 farklı kod elde edilmiștir. Madde kullanıcısı katılımcılar ve madde kullanıcısı çocuğu olan babaların deșifre metinlerinden elde edilen kodların birleștirilmesiyle ortaya çıkan bu 25 kod üzerinden yapılan değerlendirmelerde 4 farkı tema belirlenmiş̧tir.

Analiz sonrasında ortaya çıkan bulguların değerlendirmesini ve sunumunu kolaylaştırmak adına verilen alıntıların kime ait olduğunun daha net anlaşılabilmesi için alıntının hemen sonrasında așă̆ıdaki yönerge doğrultusunda bilgilendirme yapılmıştır.

\section{Madde kullanıcısı olan katılımcılar için:}

(Cemil, Bağımlı, 32, Eroin, T/K)

(Katılımcı Adı/Katıımcı Türü, Yașı, Tercih Maddesi, Temiz) Kullanımda)

\section{Madde kullanan oğlu olan babalar için:}

(Kerim, Baba, 50y, Metamfetamin, T/K)

(Katılımcı Adı/Katılımcı Türü, Yașı, Oğlunun Tercih Maddesi, Oğ/u Temiz/Kullanımda)

\section{Bulgular}

Araștırma sürecinde elde edilen verilerin analiz edilmesi sonucunda Babalarda Eksik Tedavi Katıımı, Tedaviye Katılımda Babalar için Motivasyon Kaynağı Olarak Başarı Hikayeleri ve İyileșme Arzusu, Tedavi Sürecinde Baba Katılımının Ișlevi, Tedavide Doğru Bilgi ve Iliş̦ki Ağını Yakalamak, Tedavi Sürecine Katılımda Anne ve Baba Arasındaki Farklar olmak üzere 5 tema elde edilmiştir.

Katılımcıların sosyodemografik verilerinde ve madde kullanım özelliklerinde bazı noktalar öne çıkmaktadır. Araștırmaya katılım sağlayan madde kullanıcısı grubunun yaş ortalaması 28,5'tir. Bu gruptaki katılımcıların yarısının en az bir defa bir eğitim sisteminden ayrıldığı anlaşılmaktadır. Buna ek olarak, madde kullanıcısı katılımcıların \%65'inin ilk madde deneyimi esrar kullanarak gerçekleșmiștir. Illk madde kullanım deneyimi ortalama 16,11 yașında meydana gelmiștir. Katılımcıların ortalama düzenli madde kullanım süresi 10,3 yı/2, ortalama temiz kalma süreleri ise 1,2 yıl olarak bulunmuștur.

1 Illk kullanım yaşını net olarak vermeyenlerde (örneğin K18) küçük olan alınmıştır.

2 Ortalama kullanım süresini net vermeyenlerde (örneğin K5) küçük olan alınmıștır. 
Araştırmadaki bir diğer grup olan babaların yaş ortalaması 56 olarak bulunmuștur. En az 2 çocuğu olan babaların ailelerinde madde kullanımı olan kişinin büyük çocuk olduğu görülmektedir. 9 ailede durumun bu şekilde olduğu anlașılmaktadır. Bununla beraber babaların (16) çocuklarının ilk madde kullanımından yaklaşık olarak 2,5 yıl sonra haberdar oldukları görülmektedir. Madde kullanan çocuğu olan babaların, çocuklarının ortalama madde kullanım süresi 8,5 olarak bulunurken, 13 babanın çocuğunun, babanın araştırmaya katıldığı sırada aktif madde kullanımının olmadığı, 7'sinin ise aktif kullanımının olduğu anlașılmaktadır. Babalar ile yapılan görüșmelerde, babaların çocuklarının temiz olduğuna ilişkin inançlarının çok hızlı artış gösterebildiği farkedilmiștir. Dolayısıyla 1-2 gün veya 1 haftadır madde kullanımı olmayan çocukları için "artık temiz" ifadesinin kullanılabildiği görülmüștür. Bu sebeple 1 aydan uzun süredir temiz olduğu belirtilen kişiler temiz, bir aydan daha kısa süreli madde kullanımı olmayan ya da çok düșük yoğunlukta madde kullandığı belirtiler kişiler aktif kullanıcı olarak değerlendirilmiștir. Bu değerlendirme yalnızca babaların, çocukları adına belirttikleri süreler için geçerlidir.

\section{Babalarda Eksik Tedavi Katılımı}

Madde kullanan çocuğu olan babaların, çocuklarının tedavisine yeteri kadar katıım sağlamadıkları görülmektedir.

"Bu gruplara gitmenin bir tek amacı var. Anne, babanın da gitmesi lazım. Bizim gittiğimiz grupta yirmi kiși vardı en az. Yirmi kişinin içinde üç tane erkek vardı geri on yedi tane kadın. Kocaları gelmiyordu kocaları bir geliyordu, ilk geldikleri zaman bir kere geliyorlardı bir daha gelmiyordu. Bu iș bir tek kadınla yapılacak bir iş değil. Çünkü herkes hasta. Biz biliyoruz bunu. Bir kiși șeyse herkes hasta. Kardeș de hasta, anne de hasta, baba da hasta, babanne de hasta çünkü çocukların her gün gözünün önünde eriyor. Bunun bilincini oraya giderek ögrenmek lazım. Ben de bașta yapamıyorum. Ya diyorum gitsin ben artık yapamıyorum" (Nedim/Baba, 55y, Bonzai, T.)

Nedim Bey, babaların tedavi katılımın yeterli olmadığını ve tek bir girişiminin ardından tedavi takibinin yapılmadığını belirtmektedir. Tedaviye annenin de babanın da katılması gerektiğinin altını çizen Nedim Bey, babaların bu konuda annelere kıyasla oldukça yetersiz olduğunu ifade etmektedir.

"Yenilgiyi bir bașkalarının da șahit olmasını istememekten kaynaklı babalar hep uzak duruyor. Bu bağımlılık sarmalındaki süreçte çocukların yanında hep anneleri görürsünüz. Baba sadece ve sadece o kadar mekanik ki evde doğru dürüst bir yemek sofrası hazırlamak, mutfağa girip yemeğe yardıma olmak gibi bir șey yok. Sanki girince apoletleri sökülüyor. Bir sorunla karşılașınca da ben parayı veririm. Ben olană̆ı sağlarım gerisi size kalmıș gibi bir durumla karșılașıyor." (Kasım/Baba, 55y, Eroin, T.)

Kasım Bey'in söylemleri ise babaların tedaviye daha az katılıyor olmalarını farklı bir noktadan ele almamızı sağlamaktadır. Ona göre babalar, oğullarının madde kullanımıyla birlikte topluma karșı aldıkları yenilginin görünür hale gelmemesi amacıyla tedaviden uzak durmakta ve genellikle sürecin daha mekanik parçaları ile ilgilenmektedir. Bu bağlamda bakıldı̆̆ında genel itibariyle, babaların tedavideki işlevinin maddi destek sağlamak üzerinden şekillendiği görülmektedir.

"2011'den bu yana tedavideydim yani. Babam manevi yönde o kadar karıșmazdı kendi iç dünyama vs., maddi yönde hep destek oldu. Manevi yönler için desteğimi hep annemden aldım." (Çă̆atay/Bă̆ımlı, 32y, Kokain, T.)

Babasının tedavi sürecinde genellikle maddi imkan sağlayııı olarak yer aldığını belirten Çağatay, babasından manevi bir destek göremediğinden bahsetmektedir.

"Ya var ya. Biz bunu, bu amateme götürelim dedik. Orayı istemedi beyefendi. Orda șeyler var așırı derecede bağımlılar. Ondan sonra bir yer bulduk psikolojik o da falanca yerde3. Kardeșim ya biz kimiz kim, falanca yerdeki doktorların yanına gitmek kim? Belki sizi bilginiz ondan yüz kat daha üstün ama adam orda tutmus ya muayenehanesini. Operasyoncu bunlar yani. Gittik bir iki kere. Bu ișle alakalı. Ilgilenmekten bahsediyorum. Olmadı, bașarılı olamadık. Biz bașarılı olduk diye düsünüyorum, anne baba olarak. İstiyor, yapıyoruz da. Bizim görevimiz bu artık. Ondan sonra falanca semt miydi, o da gittiği bir yer yani. Oraya gitti. O da paralı. Doktorlar șeyden geliyor amatemden geliyor. Ama bir gittiğimizde veriyoruz kardeșim bin lira, sekizyüz lira, binücyüz lira onlar da yazıyor kardeșim, yazıyor da yazıyor. Maddi olarak bittik yani. Destek diyorsun ya destek ondan bahsediyorum. Ya benim de belli bir gücüm var. Ben de belli bir yere kadar gidebiliyorum. Ya devam edeyim de sende bir ıșık yok kardeșim. Ben sana uğrașıyorum." (Ziya/Baba, 54y, Bonzai, T.)

Ziya Bey, oğlunun tedavi olmak istediği yeri kendisinin seçtiğini ancak bu seçimin ciddi maliyetleri beraberinde getirdiğini anlatmaktadır. Ziya Bey, bu maliyetler ile karşı karşıya kaldıkça tedavi sürecindeki inancının ve motivasyonunun düşebileceği düşünülmektedir.

"Sadece yatma değil șimdi yeni bir șeyler çıkartmıșlar iki ayda bir, üç ayda bir takılmak üzere palet hikayesi sonda ilaç sonra, onbes

3 Ortalama kullanım süresini net vermeyenlerde (örneğin K5) küçük olan alınmıştır. 
günde bir terapi. Bunların hepsi var. Bir hastaneye yatma bir haftalık o da. Detoks ișlemi, seansı vs. onbeș, yirmi bin lira. Altında rakamlara çıkamıyorsunuz. Tekrar hastaneden tedavi süreci diye tanımlanan bir hafta, üç gün, beș gün. Bir gün sonra kullanıma döndüğ̈̈ zaman ailede korkunç bir yıkım. Bu ekonomik faturayı bedeli ödemek zorunda olan baba için de büyük bir yıkım oluyor." (Kasım/Baba, 55y, Eroin, T.)

Kasım Bey ise madde kullanımı tedavisinin pek çok süreci içerdiğinden ve bu süreçlerin hepsinin maddi açından önemli miktarlara karşılık geldiğinden bahsetmektedir. Bütün bu maddi desteği sağlayan babanın çocuğunun yeniden kullanıma dönmesi, baba için büyük bir yıkım vesilesi haline gelmektedir. Babaların tedavi sürecindeki maddi yatırımlarının karșılık bulmayıșının, babaların ilerleyen süreçteki tedavi katılımları üzerinde etkili olabileceği düşünülmektedir.

Tedaviye Katılımda Babalar için Motivasyon Kaynağı Olarak Bașarı Hikayeleri ve İyileșme Arzusu

Madde kullanımı tedavisi sürecinde, babaların tedavi katılımını artıran ve tedaviye yönelik inancı pekiştiren bazı unsurlar bulunmaktadır. Bunlardan birisi daha önce madde kullanımı olan ancak iyileşmiş olan kişileri görmek ve onlarla tanışmaktır.

"Hep böle amatem gibi bir yere gelmiş, ordaki insanların aileleriyle konușmuș, mesela adam diyor ki onbeș, yirmi senedir uğrașıyorum, yirmi senedir böyle. Bunlar ömür boyu bırakamayacak. Bende de babam böyle bir șeye varmıștı. Babam da inanmıyordu bırakacă̆ıma ben de inanmıyordum. Ordaki hocaları eski bağımlıları görünce inanmıștı." (Caner/Bağımlı, 23y, Eroin, T.)

Caner'in söylemlerine bakıldığında babaların, uzun süredir bu sorunla uğraşan ancak mesafe alamayan kişileri görmesinin inancı ve motivasyonu düșürebildiği ancak iyileșmekte olan madde kullanıcılarını görmenin tedaviye ilișkin inancı artırabileceği anlaşılmaktadır.

“Bir sefer ben de gittim NA'ya o bașlarda. Orada görüștüm tecrübeli arkadaşlar var orada, gerçekten fedakârlık olarak orada bulunan insanlar var. Kendilerinden Allah razı olsun diyorum hem insanlık için teșekkür ediyorum maddi karșılık olmadan bu ișleri yapıyorlar. Onlarla görüștüm. Ben de ümitlendim.” (Serdar) Baba, 61y, Esrar, T.)

"Çabalıyorduk annesi olsun, ben olsun. Çabalıyorduk, çabaladıkça dibe batıyorduk. Hep beraber batıyrduk yani annesi olsun, ben olayım, o olsun. Ama ben mücadeleyi hiç bırakmadım. Anladım. Oraya gittiğimde o çocukların șeylerini gördükçe yașadıklarını gördükçe anlattıkları olayları üç sene bırakan var, iki sene bırakan var. Dedim ki benim oğlum da bırakır." (Nedim/Baba, 55y, Bonzai, T.)

"Açık. Ben orada, özel amatem ruhsatı verilmiş hastanelerde, amatemlerde oralarda buralarda bir tane bașarı hikayesi, bu sarmaldan çıkmıș insana denk gelmemiștim bir hikâyeye de ulașmamıștım. Yoktu, böyle bir bilgi yoktu. Bir karanlığın içinde ilerliyorduk, çırpındıkça da batıyorduk. Ben o açık toplantılara gittiğimde kadın, erkek, her yaștan bir sürü, birisi diyor ben bir aydır temizim, birisi bir yıldır temizim, birisi diyor 3 yıldır temizim, birisi diyor beș yıldır. Ben temiz kalmayı bașarmış bir sürü insanı bir arada gördüğümde bir umut, ben doğru yerdeyim șeyi uyandı ve devam ettim. (Kasım/Baba, 55y, Eroin, T.)

Yukarıda söylemlerine yer verilen katılımcıların ifadeleri ise birbirine oldukça benzemektedir. Her iki katılımcı da temiz olan, iyileşme sürecinde olan madde kullanıcıları ile görüşmenin, kendi çocuklarının tedavi adına ümitlenmelerini ve tedaviye yönelik daha büyük inanç geliştirmelerini sağladığını ortaya koymaktadır. Babaların bu motivasyonu geliştirmek için genellikle en büyük kaynağın kendine yardım grupları olduğu ve oradaki temiz kalmıș madde kullanıcıları ile tanıșmak olduğu anlașılmaktadır.

Bunlara ek olarak babaların tedaviye katılımını etkileyen bir diğer önemli unsur ise çocuklarının bu konudaki gayretidir.

"Etkilemez olur mu? Çocuğunda o ışığı gördün mü? Görebiliyorsan, karșındaki ıșığı görmek önemli. Ondaki ıșı̆̆ı göreceksin. O ıșığı göremezsen hiçbir șey katedemezsin. Ișı̆̆ göreceksin ıșı ̆̆. Çocukta bir heves olacak, çocuk da tamam baba ben bunu bırakıyorum baba yardımcı ol. Baba tamam buraya kadar geldim ben artık yolumu çevirmek istiyorum dese baba o zaman canını kor ortaya canını. Bırak malını mülkünü. Canını kor." (Yakup/Baba, 58y, Eroin, K.)

"Ben șimdi bunun adam olacağını bileyim her gün yanında durayım. Soğuttu beni o dereceye getirdi beni." (Necmi/Baba, 52y, Bonzai, T.)

Babanın, çocuğunun iyileșmesini etkileyebileceğini düşünen Yakup Bey, bir babanın çocuğunda iyileșmeye yönelik heves görmesinin, tedavi katılımını artırabileceğini düșündüğü görülmektedir. Benzer bir tutuma Necmi Bey'de de rastlanılmaktadır. Yakup Bey ve Necmi Bey'in ifadeleri, babaların çocuklarının yanında olmak ve tedaviye katılmak için bir ön koşulları olduğunu ve madde kullanımı tedavisi için koşullu babalık refleksi gösterdikleri düşünülmektedir. 
Tablo 2. Babaların sosyodemografik özellikleri ve çocuklarının madde kullanım özellikleri

\begin{tabular}{|c|c|c|c|c|c|c|c|c|c|c|}
\hline Katılımcılar & Yaș & $\begin{array}{l}\text { Medeni } \\
\text { durum }\end{array}$ & Eğitim & Meslek & $\begin{array}{l}\text { Evlilik } \\
\text { süresi }\end{array}$ & $\begin{array}{l}\text { Çocuk sayısı, } \\
\text { yașları ve } \\
\text { cinsiyetleri }{ }^{4}\end{array}$ & $\begin{array}{l}\text { Çocuğun } \\
\text { kullanım } \\
\text { maddesi }^{5}\end{array}$ & $\begin{array}{l}\text { İlk kullanımdan } \\
\text { ne kadar süre } \\
\text { sonra öğrendi ? }\end{array}$ & $\begin{array}{l}\text { Çocukların } \\
\text { kullanım } \\
\text { süresi }^{7}\end{array}$ & $\begin{array}{l}\text { Mevcut } \\
\text { durum }^{8}\end{array}$ \\
\hline $\begin{array}{l}\text { Namık } \\
\text { (K1) }\end{array}$ & 58 & Evli & Lisans & Maliyeci & $32 \mathrm{yll}$ & $\begin{array}{l}2 \text { Çocuk } \\
29 \text { (E), } 23 \text { (E) }\end{array}$ & Metamfetamin & $1.5-2$ yıl & $6 \mathrm{yıl}$ & Temiz \\
\hline $\begin{array}{l}\text { Turhan } \\
\text { (2) }\end{array}$ & 54 & Evli & Ortaokul & $\begin{array}{l}\text { İnşaat } \\
\text { İşçisi }\end{array}$ & 32 yıl & $\begin{array}{l}5 \text { Çocuk } \\
32(\mathrm{E}) 19(\mathrm{~K}) 16(\mathrm{~K}) \\
15(\mathrm{~K}) 5(\mathrm{~K})\end{array}$ & Metamfetamin & 3 yıl & 10 yıl & Aktif \\
\hline $\begin{array}{l}\text { Kenan } \\
\text { (K3) }\end{array}$ & 70 & Evli & Ortaokul & Esnaf & $50 \mathrm{yıl}$ & $\begin{array}{l}1 \text { Çocuk } \\
46(\mathrm{E})\end{array}$ & Bilmiyor & 7 ay & $1.5 \mathrm{yıl}$ & Temiz \\
\hline $\begin{array}{l}\text { Necmi } \\
\text { (K4) }\end{array}$ & 52 & Evli & Lise & $\begin{array}{l}\text { Fabrika } \\
\text { İşçisi }\end{array}$ & $32 \mathrm{yıl}$ & $\begin{array}{l}2 \text { Çocuk } \\
26(\mathrm{E}) 14(\mathrm{~K})\end{array}$ & Bonzai & 5 yıl & 10 yıl & Temiz \\
\hline $\begin{array}{l}\text { Ziya } \\
\text { (K5) }\end{array}$ & 54 & Evli & illkokul & $\begin{array}{l}\text { Makina } \\
\text { Imalatcı }\end{array}$ & $30 \mathrm{yll}$ & $\begin{array}{l}2 \text { Çocuk } \\
27(K), 26 \text { (E) }\end{array}$ & Bonzai & Geç öğrendi & $5 \mathrm{yll}$ & Aktif \\
\hline $\begin{array}{l}\text { İskender } \\
\text { (K6) }\end{array}$ & 46 & Evli & Illkokul & Taksici & $20 \mathrm{yıl}$ & $\begin{array}{l}4 \text { Çocuk } \\
20(\text { E), } 19(\mathrm{E}), 14 \\
(\mathrm{E}), 11(\mathrm{E})\end{array}$ & Esrar & Belirtmedi & $6 \mathrm{yll}$ & Aktif \\
\hline $\begin{array}{l}\text { Fikret } \\
\text { (K7) }\end{array}$ & 64 & Bekar & Lisans & $\begin{array}{l}\text { Makina } \\
\text { Mühendisi }\end{array}$ & $22 \mathrm{yll}$ & $\begin{array}{l}3 \text { Çocuk } \\
30(\mathrm{E}), 28(\mathrm{E}), \\
20(K)\end{array}$ & Eroin & $2-3 \mathrm{yll}$ & 12 yıl & Temiz \\
\hline $\begin{array}{l}\text { Necati } \\
\text { (K8) }\end{array}$ & 55 & Evli & Lise & Emekli & $\begin{array}{l}\text { Illk evlilik } \\
4 \text { yıl, ikinci } \\
\text { evlilik } 12 \text { yıl }\end{array}$ & $\begin{array}{l}2 \text { Çocuk } \\
26(\mathrm{E}) 10(\mathrm{~K})\end{array}$ & Kokain & $1 \mathrm{yll}$ & $7 \mathrm{yll}$ & Temiz \\
\hline $\begin{array}{l}\text { Kazım } \\
\text { (K9) }\end{array}$ & 49 & Evli & İlkokul & Kapıcı & 26 yıl & $\begin{array}{l}2 \text { Çocuk } \\
24 \text { (E) } 16 \text { (E) } \\
\end{array}$ & Bonzai & $1 \mathrm{yll}$ & $7 \mathrm{yll}$ & Aktif \\
\hline $\begin{array}{l}\text { Cemil } \\
\text { (K10) }\end{array}$ & 50 & Evli & Ortaokul & Esnaf & $29 \mathrm{yıl}$ & $\begin{array}{l}3 \text { Çocuk } \\
29(\mathrm{E}), 25(\mathrm{E}), \\
21(\mathrm{E})\end{array}$ & $\begin{array}{l}\text { Bonzai ve } \\
\text { Metamfetamin }\end{array}$ & $1 \mathrm{yıl}$ & 6 sene & Temiz \\
\hline $\begin{array}{l}\text { Haydar } \\
\text { (K11) }\end{array}$ & 57 & Evli & $\begin{array}{l}\text { Okuma } \\
\text { yazma }\end{array}$ & Emekli & $40 \mathrm{yll}$ & $\begin{array}{l}7 \text { Çocuk } \\
\text { En büyük } 26(\mathrm{E}) \text {, } \\
\text { En küçük } 16(\mathrm{~K})^{*}\end{array}$ & Uçucu & $3 \mathrm{yll}$ & 13 yıl & Temiz \\
\hline $\begin{array}{l}\text { Serdar } \\
\text { (K12) }\end{array}$ & 61 & Evli & $\begin{array}{l}\text { Yüskek } \\
\text { lisans }\end{array}$ & Emekli & $30 \mathrm{yıl}$ & $\begin{array}{l}2 \text { Çocuk } \\
\text { 32(E), } 30 \text { (E) }\end{array}$ & Esrar & 9 yıl & 12 yıl & Temiz \\
\hline $\begin{array}{l}\text { Harun } \\
\text { (K13) }\end{array}$ & 56 & Evli & Lise & Emekli & $31 \mathrm{yll}$ & $\begin{array}{l}3 \text { Çocuk } \\
30(\mathrm{E}), 26(\mathrm{E}), 11 \\
(K)\end{array}$ & Bilmiyor & 4 yıl & 8-12 yıl & Temiz \\
\hline $\begin{array}{l}\text { Tarık } \\
\text { (K14) }\end{array}$ & 51 & Evli & illkokul & Tornacı & 29 yıl & $\begin{array}{l}2 \text { Çocuk } \\
27 \text { (E), } 20 \text { (E) }\end{array}$ & Eroin & 4 ay & $10 \mathrm{yll}^{*}$ & Temiz \\
\hline
\end{tabular}

4 Birden fazla çocuğu olan katılımcılarda madde kullanımı olan kișinin yașı italik olarak yazılmıștır.

5 Bazı babaların bağımlı çocuklarında çoklu madde kullanımı bulunmaktadır. Bu bölümde babaların kullanımına en çok şahit olduğu ve öne çıkan maddeler sıralanmıștır. Bazı babalar, çocuklarının ne kullandığını bilmemektedir. Bu tabloda "Bilmiyor” olarak belirtilmiștir.

6 Babaların burada belirttiği sürelerin "en az" olarak alınmasında fayda görülmektedir. Zira babaların bu süreleri net olarak hatırlamakta güçlük çektikleri gözlemlenmiştir. Bununla beraber bazı babaların net bir süre verememiş, hatırlayamamış ya da bu konuya ilişkin herhangi bir yorumda bulunmamışlardır. Bu durumun söz konusu olduğu görüşmelerde babaların söylemleri olduğu gibi tabloya yansıtılmıştır.

7 Bu bölümde babaların verdiği sürelerin "en az" olarak alınmasında fayda görülmektedir. Zira babaların bu süreleri net olarak hatırlamakta güçlük çektikleri gözlemlenmiştir.

8 Bu bölümde babalar oğullarının ara sıra madde kullanımı olmasını da "şuan kullanmıyor" (K19) olarak belirttikleri gözlemlenmiştir. Bu araştırmada araștırmacı madde kullanım seyrini göz önünde bulundurarak aktif madde kullanıcısı ya da temiz olduğuna karar vermiștir. 
Tablo 2. Babaların sosyodemografik özellikleri ve çocuklarının madde kullanım özellikleri

\begin{tabular}{|c|c|c|c|c|c|c|c|c|c|c|}
\hline Katılımcılar & Yaș & $\begin{array}{l}\text { Medeni } \\
\text { durum }\end{array}$ & Eğitim & Meslek & $\begin{array}{l}\text { Evlilik } \\
\text { süresi }\end{array}$ & $\begin{array}{l}\text { Çocuk sayısı, } \\
\text { yașları ve } \\
\text { cinsiyetleri }\end{array}$ & $\begin{array}{l}\text { Çocuğun } \\
\text { kullanım } \\
\text { maddesi }\end{array}$ & $\begin{array}{l}\text { İlk kullanımdan } \\
\text { ne kadar süre } \\
\text { sonra öğrendi? }\end{array}$ & $\begin{array}{l}\text { Çocukların } \\
\text { kullanım } \\
\text { süresi }\end{array}$ & $\begin{array}{l}\text { Mevcut } \\
\text { durum }\end{array}$ \\
\hline $\begin{array}{l}\text { Serkan } \\
\text { (K15) }\end{array}$ & 48 & Evli & Illkokul & İnşaat & 23 yıl & $\begin{array}{l}3 \text { Çocuk } \\
22(K), 20(E), \\
10(K)\end{array}$ & $\begin{array}{l}\text { Uçucu ve } \\
\text { Skunk }\end{array}$ & $1 \mathrm{yll}$ & $2 \mathrm{yll}$ & Aktif \\
\hline $\begin{array}{l}\text { Yavuz } \\
\text { (K16) }\end{array}$ & 72 & Evli & illkokul & Emekli & 42 yıl & $\begin{array}{l}3 \text { Çocuk } \\
40(E), 38(E), \\
32(E)\end{array}$ & Bonzai & Hatırlamıyor & $6.5 \mathrm{yll}$ & Temiz \\
\hline $\begin{array}{l}\text { Kasım } \\
\text { (K17) }\end{array}$ & 55 & Evli & Lise & Esnaf & 33 & $\begin{array}{l}1 \text { Çocuk } \\
32(\mathrm{E})\end{array}$ & Eroin & $1,5 \mathrm{yıl}$ & $11 \mathrm{yıl}$ & Temiz \\
\hline $\begin{array}{l}\text { Nedim } \\
\text { (K18) }\end{array}$ & 55 & Evli & Ortaokul & Tekstil & $30 \mathrm{yıl}$ & $\begin{array}{l}2 \text { Çocuk } \\
29(K), 24(E)\end{array}$ & Bonzai & 3 yıl & 9 yıl & Temiz \\
\hline $\begin{array}{l}\text { Yakup } \\
\text { (K19) }\end{array}$ & 58 & Evli & Lise & Emekli & $30 \mathrm{yll}$ & $\begin{array}{l}3 \text { Çocuk } \\
30(E), 26(E), \\
18(K)\end{array}$ & Eroin & Çok gizleyemedi & $12-14$ yıl & Aktif \\
\hline $\begin{array}{l}\text { Necmettin } \\
\text { (K20) }\end{array}$ & 55 & Evli & illkokul & Emekli & $30 \mathrm{yıl}$ & $\begin{array}{l}1 \text { Çocuk } \\
28(E)\end{array}$ & Eroin & $2 \mathrm{yll}$ & 14-15 yıl & Aktif \\
\hline
\end{tabular}

\section{Tedavi Sürecinde Babaların Yeri ve İşlevi}

Madde kullanım tedavisine babanın katılımı tedavi sürecine destek olabileceği gibi bazı durumlarda babaların tedaviye katılımının sürece zarar verici nitelikte olabileceği görülmüștür.

"Zaten problemin çıkıș noktası o olduğu için inan ordan gelen destek insanı daha çok rahatlatıyor. Gerçekten öyle yani. Çok daha farklı bir pozisyonda olabilidik. Destek daha tam anlamıla gerçekleșiyor olsaydı. Çünkü hiçbir șey haketmiyorsun șeyi var hayatta, yaşadım. Bu cümleyi binlerce kez duymușumdur." (Yusuf/Bă̆ımlı, 28y, Kokain, T.)

Madde kullanım sürecinin tetikleyicisi olarak babasını işaret eden Yusuf, babasından gelen desteğin kendisini rahatlattığını ve daha fazla destek görmüş olsaydı, farklı bir durumda olabileceklerini düşünmektedir.

"Desteklediğini hissetsem güzel olurdu. Hala kullanırsam șöyle yaparım, kullanırsam böyle yaparım demek yerine destekleyici șekilde kullanmamı söyleseydi tabii ki de daha mutlu olurdum, daha güvende hisserdim. Belki kullanma isteğim daha az olurdu yani bilmiyorum ama illaki etkisi olurdu yani. Olumlu yönde etkisi olurdu. O hala tam tersi otoriter davranmaya çalıșıyor yani kullanırsan şöyle yaparım böyle yaparım." (Metin/Bağımlı, 27y, Kokain, K.)

Metin ise babasının tedavi sürecine destek olmadığını, bunun yerine daha tehditkar bir tavır takındığını anlatmaktadır. Babasından göreceği desteğin kendisi daha güvenli hissetmesine neden olabileceği anlaşılmaktadır.

"Abi bana yardımcı olmuyor ya hani, yardımcı oluyor desem yalan söylerim yani. Heh șöyle de bir șeyi var bana zararı da olmuyor babamın. Önceden mesela bana yardımcı olamıyordu, üstüne bir de agresif davranıyordu sert davranıyordu. Beni çıkmaza sokması, bana daha çok zarar veriyordu. Șuan bana zarar veriyor ne yararı oluyor hiçbir sıkıntı yk yani. Babam yokmuş gibi. Sadece annem varmış gibi." (Yiğit/Bă̆ımlı, 22y, Metamfetamin, T.)

Yiğit ise daha farklı bir konuya dikkat çekmektedir. Babasının tedavi sürecindeki agresif tavırlarının, tedaviyi olumsuz etkilediğini ancak son dönemde babasının olumlu bir katkısının olmadığı gibi olumsuz da bir davranışının olmadığını, aslında zarar vermese bile tedaviye katkı sağlamış olabileceğini düşündüğü görülmektedir.

"Olmadı, köstek oldu. Ben burdayım, tedavi oluyorum iște gel, napıyorsun orda Çanakkale'ye gel, tedavin bitmedi mi hala? Bin sefer anlatmama rağmen. Yalnız kalmamak için çă̆ırırdı bağımlı ya hani. Şey olsun diye. Șimdi bile arasa gel der hani. Şuan çok diyemiyor tabi ișim falan olduğu için ama yine diyor. Çok öfkelendiriyordu beni bu ama artık o kadar öfkelenmiyorum. Çok kızıyordum. Hiç durmadı tedavi konusunda yanımda." (Salih/ Bağımlı, 34y, Eroin, T.)

Salih'in tecrübesinde de baba tedaviye katılım sağlamayan, aksine tedaviyi olumsuz etkileyici bir yapı sergilemektedir.

Babaların, eğer tedaviye olumlu şekilde katkı sağlarlarsa madde kullanım tedavisinde önemli bir aktör olabilecekleri katılımcıların ifadelerinde öne çıkan unsurlar arasında yer almaktadır.

"Çok büyük etkili olabilir. Çok büyük etkili olabilir. Ne olursa olsun, o sahipleniyor. Sahiplenme, konuyu tamamen, suçlamayı oğluna bırakmayıp bunun toplumsal veya aile olarak veya bir 
anlık hata olarak bir konu olduğunu görüp, oğluna tavrı veya evladına tavrı bu yönde olursa eğer suçlaması, suçlayıcı veya daha farkı modelle yaklaşması bu çok ciddi aileden uzaklașma psikolojisinden sizi çıkartıp ben hata yaptım ama bu hatamla da ailem beni seviyor ve benim için mücadele ediyor motivasyonu oluşturma şansı çok fazla." (Sadık/Bağımlı, 34y, Bonzai, T.)

Sadık, babaların suçlayııı değil sahiplenici olarak yaklaşmasının, madde kullanan kişi için tedavi sürecinde önemli bir motivasyon kaynağı olduğunu düșündüğü anlaşılmaktadır.

"Babanın yüzde doksan etkisi var. Baba bir kere kendine çeki düzen verirse yani o çocuğu kabullenirse oğlum sen benim canımsın, ciğerimsin bu olay herkesin bașına gelebilirdi. Benim bașıma da gelebilirdi. Ben bunu oğluma anlattım. Ben ailemde görmedim ama senin bu duruma gelmen benim hatam. Senin de hatan var ama yüzde yetmiș, doksan benim hatam var. Senin de hatan olmuş gitmișsin bu ișlere bulașmıșsın ama bundan kurtulmak için de beraber hareket etmemiz lazım. Kesinlikle babanın șeyi yok. Anne zaten evladını her zaman kucaklar. Babanın burda çok büyük etkisi olduğunu düșünüyorum ben." (Serkan/Baba, 48y, Uçucu ve Skunk, K.)

Serkan Bey de, Sadık'ın söylemleriyle uyumlu biçimde babanın madde kullanım tedavisi sürecinde önemli bir etkisinin olduğunu ve babanın suçlamak veya eleștirmek yerine kabullenici tavrının, çocuğunun yanında olma çabasının tedavi sürecini olumlu etkileyeceğini düşünmektedir.

"Tedaviye getirip götürüyordu Allah razı olsun. İstanbul'a hastaneye onun sayesinde gittim geldim. Hastanede iken ben, o da aile eğitimine geldi. Gerçekten maddeyi bırakmamda onlarında etkisi var. Geldiler bana destek verdiler. Zaten dışardan size destek verdikleri zaman bırakma isteğiniz artıyor... Şahsen babam beni hastaneye tek gönderseydi gitmezdim yani... Babamla gittim gülerek gidiyorum artık iyi ki gitmișim. Öyle bir etkisi var yani." (Abdullah/Bağımlı, 26y, Karıșık, T.)

Abdullah'ın tedavi sürecinde babasının göstermiş olduğu destekleyici tavır, fiziksel ve duygusal yakınlık, Abdullah için önemli bir motivasyon kaynağı olușturmuștur.

"Kesinlikle etkiler. Tabii etkiler etkilemez mi ya. Baba bıraktığı zaman nasılsa aman diyecek yani... Ben bugün onu kapının önüne koysam o gider yani, yașayamaz. Hem maddi anlamda yașayamaz. Hem manevi anlamda yașayamaz. Çünkü çocuk gibi o. Bazı șeylerde çocuk gibi davranıyor. Hastalanmış yani netice itibariyle yani." (Serdar/Baba, 61y, Esrar, T.)

Serdar Bey'in ifadelerinde de babanın madde kullanım tedavisinde önemli bir yeri olabileceği fikri kendine yer bulmaktadır.
"Ben size diyorum ya ben hiç bırakmadım. Ben bir sene boyunca ișimi bıraktım. Beș bin lira maaș alıyordum bıraktım, bir sene o çocuğun peșinde koștum. Ama ne var, ben onun kurtulmasını istiyordum ve onda onu görüyordum bırakma șeyini. Bizim ona yaptıklarımızı o da görüyordu. Çok süreçler atlattık... Zaten bizim savașmamızla bu ișin olmadı̆̆ı ben çok iyi biliyorum. Anne babanın savașmasıyla bu ișin olmadığını çok iyi biliyorum. Kendisinin istemesi lazım. Ama ne var kendisinin istemesi için anne babasının ona yardıma olması lazım." (Nedim/Baba, 55y, Bonzai, T.)

Nedim Bey, çocuğunun yanında olmayı asla bırakmadığını belirtmektedir. Çocuğunun madde kullanımını sonlandırma yönündeki gayretini görmenin, Nedim Bey'in tedaviye ilișkin motivasyonunu ve katılımını artırıcı bir etki yapmış olabileceği düşünülmektedir. Bununla beraber Nedim Bey, ailelerin savaşının çocuğunun madde kullanımını sonlandırmasını sağlamadığını, bu meselenin madde kullanan kişinin kendi isteği ile olması gerektiğinin altını çizmektedir. Lakin ailelerin yapabileceği en büyük şeyin ise çocuklarının, bunu bırakmayı istemesini sağlamak için ona yardımcı olmak olduğunu vurgulamaktadır.

\section{Tedavi Doğru Bilgi ve İlişki Ağını Yakalamak}

Tedavi süreci içerisinde doğru bilgiye erișmek ve doğru kurulușlar ve profesyoneller ile temas kurmak hem tedavinin seyri hem de babaların tedavi ile olan ilişkilerini artırması ve daha katılımcı olmaları açısından önem arz etmektedir. Genel itibariyle bakıldığında babaların, karșı karșıya oldukları sorunun tam olarak ne olduğu bilemedikleri ve bununla nasıl mücadele edebilecekleri noktasında fikirleri olmadığı anlașılmaktadır. Bildikleri yollar tükendiğinde ve yapılan girişimler olumsuz sonuçlandı̆̆ında babalar tedavi motivasyonunu çok hızlı şekilde kaybedebilmekte ve umutsuzluğa kapılabilmektedirler.

"Bu uyușturucu maddeye odaklanınca uyușturucunun bir beyin hastalığı olduğunu anlayınca, hani o zannediyordu ki ben istediğim zaman bırakırım sanıyordu, içme diyordu ama sonra bu bağımlılığının bir beyin hastalığı olduğunu anlayınca, tedavi olmam gerektiğini anlayınca daha farklı davranmaya bașladı. O da kabullendi hastalık olduğunu ben de kabullendim." (Abdullah/ Bă̆ımlı, 26y, Karıșık, T.)

Abdullah babasının, madde kullanımına yönelik bakış açısının tedavide doğru bilgive ulașmasıyla değiștiğinden bahsetmektedir. Bu değișim, bağımlılık bir hastalık olduğunu kabul etmek ve tedavisini aramak üzerinden șekillenebilmektedir. Bu süreçte en dikkat çekici söylemler Kasım Bey’e aittir.

"Umut tüccarlı̆̆ı, hayal tüccarlı̆̆ı diye tanımlayacağımız ehil olmayan, birilerinin acısı üzerinden kendine kazanç devșirmeye çalıșan insanların rahatıkla, denetlenmeden cirit attı̆̆ı bir pazara 
dönüssmüș durumda. Birileri can derdindeyken, birileri et derdinde maalesef... Adam dernek kurmuș veya uyușturucuyla ilgili bir sayfa kurmuş. Paylaşılan dișe dokunur, beni doğru sağlıklı, nitelikli, zaman kaybetmeden, maddi manevi istismara uğramadan doğru bilgiyle doğru ilișki zincirine yöneltecek elle tutulur bir tane sayfaya ulașamıyorsunuz. Kimse ne halt edeceğini bilmiyor. Aile öyle bir durumdaki damgalanmadan, çocuk, aile etiketlenmeden bir kurtarıcı bulabilir miyim ? Hazır müșteri durumundasınız zaten." (Kasım/Baba, 55y, Eroin, T.)

Madde kullanım tedavisinin bir umut tüccarlığına dönüştüğünü ve ailelerin bu konuda istismar edildiğini anlataan Kasım Bey, babaların ve genelde ailelerin doğru bilgiye ve doğru kișilere ulaşma nokasında ciddi sorun yaşadı ̆̆ını belirtmektedir.

"Mekanizmalar o kadar karışmış ki hastaneye yatıp, ilaç tedavisine bașladıktan sonra her şey bitecek gibi. 0 kadar kısa erimli ve sığ ve kısıtlı bilgilerle bu yolculuğa herkes çıkıyor ki özellikle ve özellikle babaların direnci ve umudunun kırılması bu eksik ve yanlış bilgiden kaynaklı." (Kasım/Baba, 55y, Eroin, T.)

Kasım Bey, babaların tedavi sürecine ilişkin eksik ve yanlış bilgisinin, tedavi motivasyonunun ve umudun kırılması noktasında önemli bir işlevi olduğunu vurgulamaktadır.

"Ben çocuğumun madde kullandığını öğrendiğimde şok olmak yerine vakit ve zaman kaybetmeden, umut taciri denen insanların eline düșmeden müșteri ya da mürit gibi istismar edilmeden direk en doğru en să̆lıklı uzmanların ya da profesyonellerin denetimine adım atmış olsam çocuğum da o eziyeti çekmeyecek ben de çekmeyeceğim. ișin kriminal boyutu hırsızlık fuhuș, buralara sapmayacak belki de." (Kasım/Baba, 55y, Eroin, T.)

Madde kullanan bir çocuğu olan baba için, çocuğunun madde kullanımını öğrenmesinin ardından doğru bilgi ve ilișki ağını yakalayabilecek girişimlerde bulunulmasının önemli olduğunu vurgulayan Kasım Bey, sürecin bașında tedavi ağının doğru şekilde kurulmasının daha ileri boyuttaki sorunların oluşmasının önüne geçebileceğini ifade etmektedir.

\section{Tedavi Sürecine Katılımda Anne ve Baba Arasındaki Farklar}

Katılımcıların söylemlerinde öne çıkan noktalardan bir diğeri ise tedavi sürecinde annelerin, babalara kıyasla daha fazla çaba harcaması, daha fazla mücadele etmesi ve varlık göstermesidir.

"Yani șimdi șiddete yönelik bir șey yașamadık. Çünkü annem vardı, annem Allah razı olsun hep böyle mücadele eden taraf oldu. Babam, annemin tavrıla annem de öyle der kesinlikle korkak gibi biraz işte cesareti yoktu, bu mücadelede benim yanımda olma gibi bir șeyi yoktu yani. Tamamen hani annem olmasa gerçekten, sokağa beni koyardı yani. Ne halin varsa gör derdi." (Yusuf/ Bağımlı, 28y, Kokain, T.)
Yusuf'un ifadelerinde de görüldüğü gibi, babasıyla kurduğu ilișkinin, annesinin varlığı ve annesinin tedavi için verdiği mücadele sonucunda devam ettirilebildiği anlaşılmaktadır. Yusuf'un hikayesinde anne tedavi sürecinde ön planda yer almaktadır.

"Valla bir iște dediğim gibi ben senin yanındayım, kelime olarak bana șey veriyor mesela atıyorum ben burdayım bir defa babam beni kendi numarasından arayıp, napıyorsun demedi. Yemin ederim beni șu derneğin telefonu çalıp da hocam ya da bir arkadașım Yiğit baban arıyor demedi yani... O da yok yani beni aramaz hep annem arar hep. Her gün arar yani." (Yiğit/Bağımlı, 22y, Metamfetamin, T.)

Annesinin, babasına kıyasla tedavi sürecine daha fazla katılımcı olduğunu belirten Yiğit'in, babasının annesine göre daha az destekçi olduğu anlaşılmaktadır.

"Tedaviyi asıl babalar yönlendiriyor. Anneler kıyımsız. Anneler çaresiz. Anneler șey yapmıyor. Babalar kabullenemiyor. Benim oğlum yapamaz diyor, ya benim ailemde böyle kimse yok, ben yedirdim, içirdim, altında son model arabaları var. Görüyordum yani șöyleydi böyleydi, babalar bunu kabullenmediği sürece ben size bunu demin anlattım. Anne baba olmadan bu iș yürümez. Baba eğer bu sürece girmezse bu iș yürümez. Ben de biliyorum eğer ki ben bu sürece girmeseydim, anne bunu yapamazdı beceremezdi. Annenin sevgisi farklı, çocuklar babada bașka bir șey görüyorlar. Annesinin onu çok sevdiğini biliyor. Annesinin ona kıyamayacă̆ını biliyor ama babasından da bunu bekliyor anladınız mı, babasından da diyorki annemin bana verdiği sevgiyi babamdan da bekliyorum. Bu parayla pulla olmuyor, çocuk bunu görmek istiyor sende. Bir sarılmak, bir șakalașmak, senle gülmek, senle bir șeyleri paylașabilmek yani çocuk bunu istiyor." (Nedim/ Baba, 55y, Bonzai, T.)

Nedim Bey, tedavi sürecinde babaların annelerdan daha etkili olabileceğini ve tedaviyi babaların şekillendirdiğini düşündürmektedir. Babanın tedaviye katılımı olmaksızın bu işi bașarmanın mümkün olmadığı ifade eden Nedim Bey, çocukların anneden olduğu kadar babadan da beklentilerinin olduğunu ve bu beklentilerin yalnızca maddiyat veya fiziksel olarak var olmak değil, duygusal ihtiyaçları da içerdiğini belirtmektedir.

"Baba, anne birinden birisinin yanında olduğunu hisseden çocuk için... Erkek çocuk için baba daha önemli oluyor. Kendini daha güvende hissediyor ne hikmetse. Anneden daha farklı oluyor babanın yanında olduğunu hissetmesi..." (Fikret/Baba, 64y, Eroin, T.)

"Kız çocukları için evet anneler șey olabilir ama erkek çocuklar için babaların bilhassa yanında olması gerekiyor." (Necati/Baba, 55y, Kokain, T.) 
Hem Fikret Bey hem de Necati Bey, madde kullanan erkek çocukların tedavisinde babaların katılımının, annelerin katılımına kıyasla daha önemli olduğunun altını çizmektedir.

Annelerin tedavi sürecindeki rolünün çok büyük olduğunu belirten babalar da bulunmaktadır.

"Annesi olmasaydı biz bunu kurtaramazdık. Ailenin arkasında durması, sahiplenmesi, sokaklardan alması onu öyle kurtardık biz. Onun en yoğun kriz dönemlerinde bă̆ımlılık dönemlerinde yașadı̆̆ı sıkıntıları hem annesi arkasında durdu" (Fikret/Baba, $64 y$, Eroin, T.)

"Doğrusunu söylemek gerekise bizi toparlayan hanımdır yani. Belki hanım olmasaydı farklı yerlerde olurduk yani. Bana tepki gösteriyor yani niye çocuklara böyle konușuyorsun vs. diye. 0 zaman çok umusramiyordum ama șimdi umursuyorum. Geçen dedi ki ya bu Cenk düzelmeyecek herhalde. Dedim zamana bırakmak lazım biz elimizden geleni yapalım düzelir inșallah. Evde bir problemimiz yok çok șükür. Çocukların yanında tartıșmamız vs. olmaz. Önceden de olmazdı yani. Ben zaten çalıșıyordum yani tartıșacak zamanım da yoktu yani” (Serkan/Baba, 48y, Uçucu ve Skunk, K.)

"Ben çoğu zaman evdeydim ișe gidiyorum ama bir iki gün kalıyordum istanbul'da uzakta olduğu için ev. Annesi benden çok mücadele verdi" (Yavuz/Baba, 72y, Bonzai, T.)

Babaların bu söylemlerinin ortak noktası, annelerin tedavi sürecinde verdikleri katkıların babalar tarafından farkedilmiş olmasıdır. Alıntıları verilen katılımcılar, annelerin madde kullanım tedavisi sürecinde oynadıkları rolün ne kadar kıymetli olduğunu vurgulamaktadırlar. Bu ifadeler aynı zamanda annelerin babalara kıyasla madde kullanımı tedavisi sürecinde daha fazla katılımcı olduklarının altını çizmektedir.

\section{Tartışma}

Bu çalışmada çocuğu madde kullanan babaların, çocuklarının madde kullanım tedavisi sürecindeki konumları betimlenmeye ve bu konudaki işlevleri değerlendirilmeye çalışılmıştır. Babalar, çocuklarının madde kullanımı noktasında koruyucu bir faktör olarak görev yapabilmektedirler (17). Dolayısıyla tedavi sürecindeki konumlarının anlaşılması önem arz etmektedir.

Madde kullanımı tedavisi açısından babaların konumu genel olarak değerlendirilecek olursa, babaların bu noktada önemli bir işlevleri olduğu anlaşılmaktadır. Lakin babaların çoğunlukla çocuklarının madde kullanım tedavisine yeterli katılımı sağlamadığı görülmektedir. Babaların tedaviye katılımı genel itibariyle, maddi destek sağlamak ve koșullu olarak tedavi katılımı şeklinde gerçekleșmektedir. Kelley ve arkadașlarının çalışmalarında değindikleri üzere, madde kullanım seviyesi düșük ise tedavi katılımı daha yüksek olmaktadır (18). Ancak babaların madde kullanım sorununu geç öğrendikleri ve öğrenene kadar geçen sürede madde kullanım seviyesinin artması ve diğer veriler birlikte ele alınırsa, bu çalışmadaki babaların çocuklarının madde kullanım seviyelerinin düşük olmadığı anlaşılmaktadır. Maddi destek sağlamak ile ifade edilmek istenen, babaların tedavinin maddi yükünü çekmeleridir. Bu yönüyle aslında babaların tedaviye katılımları olduğu söylenebilmektedir. Ancak sürecin getirdiği diğer zorluklar ile mücadele etmek ve manevi anlamda destek sağlamak anneye kalmaktadır. Koşullu olarak tedaviye katılmak ise babaların çocuklarına iyileşmeye yönelik bir arzu görmeden, tedaviye katılımlarının artıș göstermemesi anlamına gelmektedir. Bu yönüyle bakıldığında babaların tedavi sürecine yalnızca maddi destek mekanizması olarak değil aynı zamanda manevi destek sağlayıcı olarak da katılım sağlamaları gerekliliği ortaya çıkmaktadır. Baba katılımı genel itibariyle babaların çocuklarının bakımına işaret etmektedir. Bu katılım; çocuğa duygusal destek sağlamak, aileye ekonomik destek sağlamak, çocukla ve aile ile kaliteli vakit geçirmek şeklinde özetlenebilmektedir (19). Buradan bakıldığında bağımlılık tedavisinde baba katılımının ise; hatalara karşı toleranslı, duygusal destek sağlayan, maddi destek sağlayan, tedavinin aktif olarak içerisinde yer alan babalar ile ifade edilebileceği düșünülmektedir.

Babaların tedavi sürecinde önemli işlevlerinin bulunduğu ve tedaviye katılımlarının, madde kullanıcıları açısından istenilen sonuçlara ulașmada önemli bir yer tutabileceği düşünülmektedir. Babaların çocuklarının madde kullanımı açısından önleyici bir rollerinin bulunduğu bilinmektedir (20). Nitekim katılımcılar da babaların tedaviye katılımının, tedaviyi olumlu etkileyebileceğini düşünmektedirler. Babaların, çocuklarının madde kullanımını önleme noktasında etkili oldukları düşünülürse, çocuklarının yeniden madde kullanımını önlemede ve temizliğin sürdürülmesinde de etkili konumda olabilecekleri düșünülmektedir. Bununla beraber, babaların aktif tedavi katılımları, her zaman olumlu sonuçlar vermemektedir. Babaların süreç içerisindeki deneyimleri ve madde kullanan çocuğu ile kurduğu ilișkiler, babaların tedavi katılımını tedavi sürecine zarar verebilecek bir noktaya dahi getirebilmektedir. Dolayısıyla babaların tedavi katılımının zarar verici bir yönü olabileceği de unutulmamalıdır. Nitekim babaların tedavi süreci içerisinde destekleyici olmayan tavırlar takınması, çok çabuk umutsuzluğa kapılması ve tedaviye olan inancının düșmesi, tedavi sürecini olumsuz etkileyebilecek unsur olarak değerlendirilmektedir. Şimşek ve arkadașlarının (21) madde kullanıcılarının tedavisi sürecinde tedaviden ayrılmayı etkileyen unsurları inceledikleri çalıșmada, tedaviden ayrılan danıșanların önemli bir kısmının babasıyla ilișkisinin olumsuz olduğu bulunmuştur. Dolayısıyla babaların tedavi süreci içerisinde olumsuz etkileri olabileceği anlaşılmaktadır. 
Bu sebeple babaların bağımlılık süreçleri hakkında eğitilmeleri önem tașımaktadır. Bu eğitim süreci, tedavi alan çocuğunun perspektifini alabilmeyi, tedaviye katılıma yönelik motivasyonel görüşmeleri içermesi hem olumsuz sonuçları azaltabilmesi hem de olumlu çıktıları destekleyebilmesi açısından önem taşımaktadır.

Babaların tedavi sürecine aktif olarak katılma noktasında yașadıkları çeșitli sorunlar bulunmaktadır. Bu sorunların bașında; yüksek beklentiye sahip olmak ve bunlara hızlıca erișmeyi beklemek, tedavi çıktılarının veya tedavinin sonuçlarının etkisini somut yaşamda bir an önce farkedebilme arzusu, tedavi sürecinin doğasından kaynaklanabilen geri adımları sebebiyle çok hızlı şekilde umutsuzluğa kapılarak, motivasyon kaybı yașayabilmek ve hatalara karşı tahammülsüzlik olarak ifade edilebilmektedir. Genel itibariyle bakıldığında baba tutumları ve tedavi sürecinin birbiriyle uyumsuz özellikler sergilediği görülmektedir. Bu tutum ve davranışların baba ve çocuk arasındaki çatışmaları artırabileceği düşünülmektedir. Nitekim yapılan çalışmalar, baba ve çocuğu arasındaki çatışmaların, madde kullanım şiddetini artırabileceğini ortaya koymaktadır (22). Tedavi sürecinde; zaman, hatalara tahammülsüzlük, destek sağlamak ve motivasyon önemli bir nitelik tașımaktadır. Bu sürecin sonunda ise babalarda; suçlayıcı davranışlar, güven kaybı yaşama, yüksek kontrol ve sıkı takip gibi davranışlar ortaya çıkabilmektedir. Tedavi sürecine fzarar verebilecek böylesi tutum ve davranışların, süreç içerisinde muhakkak ele alınması gerektiği düşünülmektedir. Bununla beraber babaların tedavinin maddi yükünü çekmelerinin, hatalara karșı daha az tahammülkar ve destekleyici olmalarının önüne geçebildiği anlașılmaktadır. Zira babaların tedavi için sağladıkları maddi destek, çocuklarının süreç içerisinde başarılı olmalarına yönelik bir beklenti olarak geri dönmektedir. Ancak relapslar ile ilerleyen bir yapı sergileyen madde kullanımı tedavisinde hızlı sonuç almak ve hatalara rastlamamak her zaman için mümkün değildir. Nitekim babaların bu tutumu, tedavi sürecinden erken kopmalarına neden olabilmektedir. Parent ve arkadaşlarının 2017 yılında psikolojik açıdan zorluklar yaşayan çocukların, babaların katılımını inceledikleri çalışmalarında babaların, annelere kıyasla tedaviden daha erken ayrıldıkları bulunmuștur (23).

Babaların beklenti sahibi olmaları ve tedavi sürecinde bunların karșılanmaması, baba ve çocuğu arasındaki ilișkinin daha gerginleşebileceğine işaret olarak değerlendirilebilmektedir. Babaların, çocuklarının madde kullanımı sebebiyle yaşadıkları hayal kırıklığına, verdikleri mücadeleye rağmen çocuklarının madde kullanımını sürdürmesi de eklendiğinde ortaya çıkan duyguların, babaları hem tedaviden hem de çocuğu ile destekleyici bir ilișki kurmaktan uzak tutabilecek potansiyele sahip olduğu anlaşılmaktadır. Bunun yerine babaların tedavi sürecinde daha destekleyici bir yapıda olması, sürecin sağı̆̆ı açısından önem taşımaktadır. Nitekim, Coombs ve Landsverk tarafından yapılan bir çalışmada madde kullanımını sonlandıran kişilerin, sonlandırmayanlara göre babalarıyla daha iyi ilişkileri olduğunu bildirdikleri, kendilerini babalarına yakın hissettikleri ve sorunlarını babalarıyla konuşabildikleri belirtilmektedir (24). Lakin babaların, tedavi sürecinde destekleyici bir yapı sergilemeleri için önce çocuklarının tedavi için arzulu olmalarını bekledikleri görülmektedir. Bu yönüyle babalar, çocuklarına destek vermek adına önce çocuklarından bir işaret beklemektedirler. Bu ișaret gelmediğinde de babaların destekleyici tutumu ve aktif tedavi katılımı vasat düzeyde süregelmektedir. Babaların tedavi katılımını ve destekleyici tutumlarını etkileyebilecek unsurlardan birisi çocuklarından tedaviye yönelik bir arzu görmek iken, bir diğeri ise eski madde kullanıcılarını veya iyileșmiş madde kullanıcılarını görmek ve onlarla tanışmaktır. Babalarda bu iki unsurun, tedavi sürecine yönelik motivasyon artırıcı nitelikler taşıdığı görülmektedir. Tedavi katılımını artıran babaların, madde kullanan çocuklarına karșı daha duyarlı tutum ve davranışlara sahip oldukları fark edilmektedir. Bu duyarlılık ise çocuklarını daha fazla kontrol etme ve madde kullanım davranışını takip etmeyi beraberinde getirmesi olasıdır. Bogenschneider ve arkadaşlarının yaptığı çalışmada babaların, çocuklarını takip etmesi ve gözlemlemesinin madde kullanımı üzerinde negatif bir etkisi olduğu bulunmuştur (25). Bu doğrultuda babaların tedavi katııımı için bir beklentiye girmeden sürece dahil olmalarının, ilerleyen dönemde daha sağlıklı sonuçlar doğuracağı düşünülmektedir.

Madde kullanım sorunu kendini gösterdiğinde ve babaların bildikleri yollar ile giriștikleri mücadeleler sonuç vermediğinde, ne yapacağını ve çocuğuna nasıl destek olacağını bilmeyen bir baba profili ortaya çıkmaktadır. Bu süreç içerisinde doğru bilgi ve ilișkilere ulașmakta zorlanan babaların, doğru kanalları bulana kadar tecrübe ettikleri tedavi girișimlerinin olumsuz sonuçlanması, babaların tedavi motivasyonlarını ve destekleyici tutumlarını azaltabilmektedir. Dolayısıyla bu süreç içerisinde babaların olabilecek en hızlı şekilde doğru kaynaklardan bilgi almaya ve doğru kişiler ile irtibat kurmaya intiyaç duymaktadırlar. Bunun tedavi sürecinin yıpratıcılığını azaltması gibi bir ișlevinin de olabileceği düşünülmektedir. Nitekim, çabuk motivasyon kaybı yașayan, umutsuzluğa kapıldığı bilinen babaların başarısız tedavi girișimlerinin, tedaviye olan inancı azaltabildiği anlaşılmıştır. Her ne kadar babaların tedaviye olan inançları hızlıca kaybolabiliyor olsa da Bagner ve Eyberg tarafından yapılan bir çalıșmada babaların ebeveyn eğitim programlarına katııımının ardından süreçte direkt ve hızlı bir etki olmadığından ancak babaların katılımının sağıklı ilerleme kaydedebilmek adına önemli olduğundan bahsedilmektedir (26). Madde kullanım tedavisi için bakııdığında da benzer durumların söz konusu olabileceği düșünülmektedir. 
Genel itibariyle bakıldığında madde kullanımı tedavisine katılımda anneler ve babalar arasında önemli farklılıklar bulunmaktadır (27-29). Bu farklılık genel olarak ruh sağığı alanında da göze çarpmaktadır. Mackenzie ve arkadaşlarının yaptığı çalıșmada, annelerin babalara kıyasla ruh sağlığı desteği alma girişiminde daha talepkar olduğu bulunmuştur (27). Anneler, babalara kıyasla daha katılımcı bir yapı sergiledikleri ve daha yoğun ve uzun süreli destekleyici tutumlara sahiptirler. Babaların söylemlerinin de bu yönde olduğu görülmektedir. Ancak yine de Shek ve arkadașlarının çalıșmalarında bahsettiği üzere babaların çocuklarının sosyalleșmesinde ve madde kullanımlarının engellenmesinde annelere kıyasla daha güçlü bir rol oynayabilmektedirler (28). Bununla beraber, Mackenzie ve arkadașlarının çalıșmasının sonuçları düşünüldüğünde annelerin ruh sağ|ığı için destek almaya yönelik daha güçlü taleplerinin ve bakıs açısına sahip olması, aynı zamanda tedaviye katılımlarını da artıı bir etki yapabilmektedir (27). Lakin tedavi süreci içerisinde özellikle erkek çocuklar için babalarının desteğinin çok önemli olduğunun altı çizilmekte ve annelerin tedavi katıımının, babaların tedavi katılımı ile aynı etkiye sahip olmadığı ifade edilmektedir.

Bu araştırmanın bazı sınırlılıkları bulunmaktadır. Bunlardan birincisi araștırmada madde kullanıcısı örnekleminin tamamının erkeklerden olușmasıdır. Bunun en önemli sebebi, kadın madde kullanıcılarına ulașmada yașanan zorluktur. Bu yönüyle bu çalıșma babalar ve oğullarını kapsayan bir niteliğe bürünmüştür. Daha derinlemesine analizler için kadın katılımcıların da dahil olduğu çalıșmaların yürütülmesi gerektiği düşünülmektedir. Çalışmanın önemli bir diğer sınırlıı̆̆ı ise katılımcılar ile belirli bir zamanda tek seferlik görüșmelere dayanmasıdır. Bu durum özellikle süreç okuması açısından bazı zorlukları bünyesinde barındırmaktadır. Kişilerin tedaviye ilk başvurdukları dönem ve sonrasındaki süreç için periyodik görüşmelerin planlanması ve değişimlerin bu bağlamda izlenmesi daha güçlü sonuçlara ulașılmasını sağlayabilir.

Sonuç olarak madde kullanımı tedavisinde babaların, tedaviye düșük düzeyde katılım gösterdikleri anlașılmaktadır. Dolayısıyla bağımlılık sürecinde babalar, çocuklarının tedavisi noktasında daha görünmez bir yapı sergilemektedirler. Babaların tedaviye katılımları ise genellikle 2 boyutta gerçekleșmektedir. Bunlardan en yaygın olanı, maddi destek sağlayıı olarak tedaviye katılmaktır. Tedavi sürecinin maaliyetini karșılamanın, bir her ne kadar aktif bir rol oynamıyor olsa da tedavi katılımının bir çeșiti olarak değerlendirilebileceği düșünülmektedir. Bir diğer ise koșullu olarak tedavi katılımıdır. Bu noktada ise babalar, çocuklarından tedaviye yönelik bir arzu ve çaba görmeyi beklemektedirler. Ancak bu durumda tedaviye daha aktif katıım sağlayabilmektedirler. Hızlı ve yüksek beklenti içine girmek, umutsuzluğa kapılmak, hayal kırıklığı yaşamak ve hatalara karșı sabırlı olamamak babalarda tedavi sürecinde öne çıkan özelliklerdir. Babaların tedavi katılımları, genel itibariyle olumlu tedavi çıktılarıyla özdeșleșiyor olsa da, yukarıda anılan özelliklerden dolayı babanın katılımı, bazen tedavi sürecini olumsuz etkileyecek niteliğe de bürünebilmektedir. Bu sebeple babanın, tedavi süreci içerisindeki varlı̆̆ının, pozitif destek sağlamak koşuluyla işlevsel olabileceği düşünülmektedir. Tedavi sürecine katılmakta sorun yașayan veya daha önce anılan özellikleri sergileyen babaların, tedavi motivasyonlarını artırmak için temiz kalmış madde kullanıcıları ile tanışmaları önem arz etmektedir.

\section{Kaynaklar}

1. Bagner DM, Eyberg SM. Father involvement in parent training: when does it matter? J Clin Child Adolesc Psychol 2003; 32(4): 599-605.

2. Begum F, Mahmood SI. Exploring psychological correlates of peers and fathers of drug addict adolescents. Dhaka University Journal Of Biological Sciences 2019; 28(1): 9-20.

3. Bess B, Janus S, Rifkin A. Factors in successful narcotics renunciation. Am J Psychiatry 1972; 128(7): 861-865.

4. Bischof G, Iwen J, Freyer-Adam J, Rumpf HJ. Efficacy of the community reinforcement and family training for concerned significant others of treatment-refusing individuals with alcohol dependence: a randomized controlled trial. Drug Alcohol Depend 2016; 163, 179-185.

5. Bogenschneider K, Wu M, Raffaelli M, Tsay JC. Parent influences on adolescent peer orientation and substance use: the interface of parenting practices and values. Child Dev 1998; 69(6): 1672-1688.

6. Caliendo C, Senese VP, Cantone D. Parental rejection, addiction and current fathering: a comparative study. Rivista Di Psicologia Clinica 2017; 1: 59-69

7. Coombs RH, Landsverk J. Parenting styles and substance use during childhood and adolescence. J Marriage Fam 1998; 50(2): 473-482.

8. Copello A, Velleman R, Templeton L. Family interventions in the treatment of alcohol and drug problems. Drug Alcohol Rev 2005; 24(4): 369-385.

9. Creswell JW. Nitel Araştırma Yöntemleri: Beș Yaklașıma Göre Nitel Araștırma ve Araștırma Deseni. Bütün M, Demir SB. (Çevirenler) 2. Baskı, Ankara: Siyasal, 2016.

10. Eldred CA, Brown BS, Mahabir C. Heroin addict clients description of their families of origin. Int J Addict 1974; 9(2): 315-320.

11. Garey Al, Arendell T. Children, work, and family. Hertz R, Marshall NL (editors). Working Families: The Transformation of The American Home, University of California Press, 2001.

12. Gearing RE, Selkirk EK, Koren G, et al. Perspectives of mothers with substance use problems on father involvement. J Popul Ther Clin Pharmacol 2008; 15(1): e99-e107.

13. Hornberger S, Smith SL. Family involvement in adolescent substance abuse treatment and recovery: What do we know? What lies ahead? Child Youth Serv Rev 2011; 33(Suppl 1): S70-S76.

14. Kahyaoğlu G, Dinç M, Ișık S, Ögel K. Effects of engaging family in addiction treatment for substance use and treatment compliance: A preliminary study. Addicta 2020; 7(4): 229-233

15. Kelley ML, D’Lima GM, Henson JM, Cotten C. Substance-abusing mothers and fathers' willingness to allow their children to receive mental health treatment. J. Subst. Abuse Treat 2014; 47(1): 106-111.

16. Kirby KC, Marlowe DB, Festinger DS, et al. Community reinforcement training for family and significant others of drug abusers: A unilateral intervention 
to increase treatment entry of drug users. Drug Alcohol Depend 1999; 56(1): 85-96.

17. Leshner Al. (1997). Addiction is a brain disease, and it matters. Science 1997; 278(5335): 45-47.

18. Mackenzie CS, Scott T, Mather A, Sareen J. Older adults' help-seeking attitudes and treatment beliefs concerning mental health problems. Am J Geriatr Psychiatry 2008; 16(12): 1010-1019.

19. Orford J. Empowering family and friends: a new approach to the secondary prevention of addiction. Drug Alcohol Rev 1994; 13(4): 417-429.

20. Ögel K. Bağımlılık ve Tedavisi Temel Kitabı. 1. Baskı. IQ: İstanbul. 1990

21. Parent J. Forehand $\mathrm{R}$, Pomerantz $\mathrm{H}$, et al. Father participation in child psychopathology research. J Abnorm Child Psychol 2017; 45(7): 1259-1270.

22. Shek DTL, Zhu X, Dou D, Chai W. Influence of family factors on substance use in early adolescents: a longitudinal study in Hong Kong. J Psychoactive Drugs 2019; 52(1): 66-76.

23. Strauss A, Corbin J. Basics of Qualitative Research. New York: Sage, 1990.
24. Strega S, Fleet C, Brown L, Dominelli L, et al. Connecting father absence and mother blame in child welfare policies and practice. Child Youth Serv Rev 2008; 30(7): 705-716.

25. Şimșek M, Dinç M, Ögel K. Determinants of the addiction treatment drop-out rates in an addiction counseling centre: a cross-sectional study. Psychiatr. Clin. Psychopharmacol 2019; 29(4): 446-454.

26. Wang J, Simons-Morton BG, Farhart T, Luk JW. Socio-demographic variability in adolescent substance use: mediation by parents and peers. Prev Sci 2009 ; 10(4): 387-396.

27. Wong JJ, Cucciare MA, Booth BM, Timko C. Predicting substance use patterns among rural adults: the roles of mothers, fathers, and parenthood. Fam. Proc 2019; 58(2): 431-445.

28. Yıldırım A, Șimșek H. Sosyal Bilimlerde Nitel Araștırma Yöntemleri. 10. Baskı Ankara: Seçkin. 2016.

29. Yoon S, Pei F, Wang X, et al. Vulnerability or resilience to early substance use among adolescents at risk: The roles of maltreatment and father involvement. Child Abuse Negl 2008; 86: 206-216. 